\title{
Purification and Characterization of Milk Clotting Enzyme from Edible Mushroom (Pleurotus florida)
}

\author{
Ashraf Bakr ${ }^{1}$ (D) , Osama Ibrahim ${ }^{2, * i D}$, Abd El-Sattar El-Ghandour ${ }^{3}$ iD , Noha El-Deeb ${ }^{3(D)}$ \\ Food Science \& Technology Department, Tanta University, Egypt; ashraf.bakr@agr.tanta.edu.eg (A.B.); \\ Dairy Science Department, National Research Centre, Cairo, Egypt; osama_nrc@ hotmail.com (O.I.); \\ Dairy Technology Department, Animal Production Research Institute, Dokki, Egypt; dr.elghandour@yahoo.com (A.E.); \\ nanosh66@yahoo.com (N.E.); \\ * Correspondence: osama_nrc@hotmail.com (O.I.);
}

Scopus Author ID 56819417700

Received: 5.08.2021; Revised: 28.08.2021; Accepted: 30.08.2021; Published: 4.09.2021

\begin{abstract}
Oyster mushroom (Pleurotus florida $14 \mathrm{MICC}$ ) is one of the most widely cultivated edible fungi in the world. Milk clotting enzyme (MCE) derived from the mold was developed as a calf rennet alternative; thus, it was purified and characterized, and its effect on different milk species was investigated. The highest MCE activity $(75.49 \mathrm{SU} / \mathrm{ml})$ was observed in mushroom fruit bodies dissolved in $0.2 \mathrm{M}$ sodium acetate $\mathrm{pH} 5.0$; as well as the highest total MCE activity (367.85 SU) was recorded at $20 \%$ of ammonium sulfate with a specific activity of $343.79 \mathrm{SU} \mathrm{mg}^{-1}$ protein while size exclusion column chromatography on Sephadex G-100 purified MCE 3.46-fold with $17.96 \%$ yield. Also, it could be capable of coagulating different milk species. Mushroom MCE exhibited their optimal activity at $\mathrm{pH}$ 5.0 for crude extract (CE) while at $\mathrm{pH} 6.0$ for partial purified (PP) and purified (P) MCE fractions; as well as at $55{ }^{\circ} \mathrm{C}$ for $\mathrm{CE}$ and PP MCE fractions while $50{ }^{\circ} \mathrm{C}$ for $\mathrm{P} \mathrm{MCE} . \mathrm{CaCl}_{2}$ concentration $(0.01 \%)$ recorded the maximal activity for CE while $(0.04 \%)$ and $(0.02 \%)$ for PP and P fractions, respectively. It could be concluded that MCE from Oyster mushroom may be a good candidate as a calf rennet substitute in cheese production.
\end{abstract}

Keywords: milk clotting enzyme; oyster mushroom; calf rennet substitute; coagulant.

(C) 2021 by the authors. This article is an open-access article distributed under the terms and conditions of the Creative Commons Attribution (CC BY) license (https://creativecommons.org/licenses/by/4.0/).

\section{Introduction}

Calf rennet considers the oldest known application of enzymes in cheese making [1] as a traditional milk clotting enzyme (MCE) obtained from the fourth stomach of suckling calves, which consists of chymosin (EC 3.4.23.4) as the major coagulating component, as well as pepsin (EC 3.4.23.1) as a proteolytic enzyme [2]. Chymosin is known for its high specificity for releasing the caseinomacropeptide from $\kappa$-casein, which triggers the destabilization of the casein micelles, which induces milk clotting [3], whereas pepsin is much less specific and hydrolyses bonds with Phe, Tyr, Leu, or Val residues [4].

However, the use of calf rennet may be limited for religious reasons (e.g., Judaism and Islam), diet (vegetarianism), or consumer concern regarding genetically engineered foods (e.g., Germany, Netherlands, and France forbid the use of recombinant calf rennet) [5] Since cheese is a popular dairy product worldwide, the demand of milk coagulant has rapidly increased as the cheese production increased [6] Thus, much research interest has been directed towards discovering calf rennet alternative for cheese making from the microbial origin as an attempt to meet the demand for milk coagulants for cheese making. 
Fungi belong to the microbial diversity, which is generally regarded as safe (GRAS), and their extracellular enzymes are easily recovered in bioprocess [7]. Among fungi, mushrooms are macrofungi which belong to basidiomycetes and ascomycetes. Oyster mushroom is one of the most widely cultivated edible fungi in the world [8]. Thus, MCE derived from mold has been developed as a calf rennet alternative such as Rhizomucor miehei, Rhizomucor pusillus, Cryphonectria parasitica [9], Mucor circinelloides [10], Mucor thermohyalospora, Rhizopus azygosporus [11], and Aspergillus oryzae [12] have been established. As regard mushroom species, Moharib 2007 [13] reported that Pleurotus sajorсаju STCPI-27 mushroom could be used as a source of protease enzymes with proteolytic and MCE activities. Also, Nakamura et al. (2014) [14] explored MCE-producing strains among mushrooms consumed routinely, including Hericium erinaceum MAFF 435060, MAFF 430234, and NBRC 100328, which were used in cheese making. Shamtsyan et al. (2014) [15] identified edible basidial mushroom Coprinus lagopides novel active producer of MCE as a calf rennet substitute in cheese production. Sato et al. (2016) [16] found that MCE from $H$. erinaceum MAFF 435060 coagulates heat-treated milk at both $66{ }^{\circ} \mathrm{C}$ for $30 \mathrm{~min}$ and $130{ }^{\circ} \mathrm{C}$ for 2 sec. Furthermore, Martim et al. (2017) [7] recorded that Pleurotus albidus as an edible mushroom is considered an available source of milk clotting protease.

Although the scientific interest focused on the nutritional value and medicinal properties of edible oyster mushroom which opened a new area to study their biologically active substances, where it's used as a source of MCE as well as the study of their biochemical characteristics is still limited to investigate their technological suitability in cheese production. Therefore, the present work aimed to extract and purify MCE from edible oyster mushroom (Pleurotus florida) available in Egypt as a calf rennet substitute in cheese production. Moreover, the biochemical characteristics of mushroom MCE, and its effect on different milk species were investigated.

\section{Materials and Methods}

\subsection{Raw material and chemicals.}

Dried fruiting bodies of oyster mushroom Pleurotus florida 14 MICC were obtained and identified from Central Laboratory for Agricultural Climate, Agricultural Research Center, Giza, Egypt. The dried samples were ground into a fine powder by laboratory mill and store in closed containers at $4{ }^{\circ} \mathrm{C}$ until use (Figure 1). Skim milk powder was purchased from BIELMLEK Spoldzielniamleczrska, Poland. All other reagents and chemicals were used in analytical grade.

\subsection{Methods.}

\subsubsection{Extraction of MCE from the oyster mushroom.}

MCE activity was detected in different extracts of oyster mushroom (Pleurotus florida $14 \mathrm{MICC}$ ) using 0.2 M acetate buffer $\mathrm{pH} 5.0,0.2 \mathrm{M}$ citrate buffer $\mathrm{pH}$ 5.0, and distilled water at the level of $10(\mathrm{w} / \mathrm{v})$ which was stored for $48 \mathrm{~h}$ at $5{ }^{\circ} \mathrm{C}$. The recovered supernatants resulting from the cooling centrifugation of extracts $\left(5000 \mathrm{rpm}\right.$ for $20 \mathrm{~min}$ at $\left.5{ }^{\circ} \mathrm{C}\right)$ were considered crude enzymatic extract, and then MCE activity and protein content were determined. 
2.2.2. Purification of oyster mushroom MCE.

\subsubsection{Ammonium sulfate precipitation (ASP).}

The selected crude enzymatic extract was partially purified using ammonium sulfate to $90 \%$ saturation at $5{ }^{\circ} \mathrm{C}$, according to Colowick and Kaplan (1955) [17]. MCE activity and protein content of the recovered fractions were determined. The rich active fraction was dialyzed using $0.2 \mathrm{M}$ acetate buffer $\mathrm{pH} 5.0$ for $24 \mathrm{~h}$ at $5{ }^{\circ} \mathrm{C}$ for further purification.

\subsubsection{Size exclusion column chromatography on Sephadex G-100.}

The dialyzed fractions were further purified by applied on Sephadex G-100 (SigmaAldrich, Germany) column $(2.5 \times 20 \mathrm{~cm}$, Pharmacia, Uppsala, Sweden $)$, equilibrated with 0.2 $\mathrm{M}$ acetate buffer $\mathrm{pH} 5.0$, and the sample eluted with the same buffer. The recovered fractions were assayed for MCE activity and protein detection at OD $280 \mathrm{~nm}$. The rich fractions of MCE activity were pooled and considered as purified oyster mushroom MCE.

\subsubsection{Electrophoresis of MCE fractions.}

MCE molecular weight and purity were determined by Sodium Dodecyl SulphatePolyacrylamide Gel Electrophoresis (SDS-PAGE) method according to Laemmi (1970) [18]. The protein samples were loaded for electrophoresis at $50 \mathrm{~V}$, performed in a vertical slab gel apparatus in $12.5 \%$ polyacrylamide separating gel and $4 \%$ stacking gel. Protein samples were visualized by Coomassie brilliant blue $\mathrm{R}-250$. The pre-stained standard proteins in the range of $10-250 \mathrm{kDa}$ (Thermo scientific) were used as a molecular weight marker.

\subsubsection{MCE activity assay.}

The MCE activity of all resulted enzymatic extracts was measured according to the method of IDF (1992) [19]. Milk clotting activity is expressed in terms of the Soxhlet unit. One Soxhlet unit (SU) of milk clotting activity was defined as the amount of enzyme required to clot $1 \mathrm{ml}$ of the substrate within $40 \mathrm{~min}$ at $35{ }^{\circ} \mathrm{C}$. Soxhlet units were calculated using the following equation according to IDF (1992) [18], SU/ml = M×2400/E× t

Where $\mathrm{M}$ is the volume of substrate $(\mathrm{ml})$; $\mathrm{E}$, is the amount of enzyme extract ( $\mathrm{ml})$ and $\mathrm{t}$, is the clotting time (sec).

\subsubsection{Determination of proteolytic activity.}

The proteolytic activity of crude, partially purified, and purified enzymatic extracts were determined according to Chopra and Mathur (1983) [20]. One unit of proteolytic activity is defined as the amount of enzyme required to release TCA-soluble fragments giving a blue color equivalent to one $\mu \mathrm{g}$ of tyrosine (Sigma-Aldrich, Germany) under the standard assay condition.

\subsubsection{Protein content determination.}

The protein content in all enzymatic extracts was determined as described by Bradford's (1976) [21] procedure using Coomassie brilliant blue G-250 dye (Bio-Rad, USA). The developed color was measured at $595 \mathrm{~nm}$ using UV 1201-vis spectrophotometer Shimadzu, 
Japan. The protein concentration is calculated from a calibration curve of bovine serum albumin (Mallinckrodf, France).

2.2.7. Specific MCE activity calculation.

The specific MCE activity is calculated by divided the MCE activity (SU/ml) by the protein content $(\mathrm{mg} / \mathrm{ml})$.

2.2.8. Biochemical characterization of mushroom MCE.

\subsubsection{Optimum $\mathrm{pH}$.}

The MCE activity was measured at different $\mathrm{pH}$ values ranging from 3-8 using $0.2 \mathrm{M}$ Acetate buffer ( $\mathrm{pH}$ 3.0-5.0),0.2 M phosphate buffer ( $\mathrm{pH}$ 6.0-7.0), and 0.2 M Tris-HCl buffer $(\mathrm{pH}$ 8.0)in order to define its optimum $\mathrm{pH}$ of MCE reaction.

\subsubsection{Optimum temperature.}

The MCE optimal reaction temperature was determined after the reaction was performed at different temperatures ranging from 35 to $65^{\circ} \mathrm{C}$.

\subsubsection{Effect of $\mathrm{CaCl}_{2}$ concentration on $\mathrm{MCE}$ activity.}

The MCE activity was measured using skim milk dissolved in different concentrations of $\mathrm{CaCl}_{2}$ ranging from $0.01-0.05 \%$.

\subsubsection{Effect of $\mathrm{NaCl}$ concentration on MCE activity.}

The presence of 1.0-5.0\% NaCl in all resulted MCE fractions was studied. The residual MCE activity was measured under standard assay conditions, while the sample without any addition served as a control (100\%).

\subsubsection{Thermal stability.}

MCE was pre-incubated at different temperatures ranging from 40 to $70{ }^{\circ} \mathrm{C}$ for 15,30 , and $60 \mathrm{~min}$, and then the residual MCA was determined.

\subsubsection{Determination of MCE activity on different milk types.}

MCE activity was determined using different milk types as a substrate, such as a cow, buffalo, goat, and sheep.

\subsubsection{Statistical analysis.}

SAS statistical software performed all statistical analysis of results (SAS, 1999) [22] using the ANOVA procedure to analyze variance. The results were expressed as mean \pm standard error, and the differences between means were tested for significance using Duncan's multiple ranges at $p \leq 0.05$. 


\section{Results and Discussion}

The genus Pleurotus has been used to study the production of different enzymes and secondary metabolites due to it is an edible fungus. Also, research regarding the edible mushroom increased mainly due to integrating the information generated by genomics, proteomics, transcriptomics, and metabolomics [23]. Therefore, oyster (Pleurotus florida 14 MICC) mushroom was used as dried fruiting bodies to produce MCE as a calf rennet substitute to meet the demand for milk coagulants for cheese production. Hence, MCE is extracted and purified from an oyster mushroom with successive purification processes such as ASP and gel filtration chromatography. Moreover, its biochemical characteristics, as well as their coagulating activity on different milk species, were investigated.

\subsection{Extraction of MCE from the oyster mushroom.}

MCE activity was determined on dried fruit bodies of oyster (Pleurotus florida 14 MICC) mushroom (Figure 1) using different extraction buffers as presented in Table 1. It could be noticed that the highest MCE activity $(75.49 \mathrm{SU} / \mathrm{ml})$ and its specific activity $(356.08 \mathrm{SU} / \mathrm{mg}$ protein) was observed in oyster mushroom dissolved in $0.2 \mathrm{M}$ sodium acetate buffer $\mathrm{pH} 5.0$, followed by citrate phosphate $\mathrm{pH} 5.0$ and distilled water. Similar findings are reported with Martim et al. (2017) [7], who detected MCE on edible mushrooms, including Pleurotus albidus DPUA 1692 with 73.39 U/ml. However, MCE activity detected in oyster (Pleurotus florida 14 MICC) mushroom is slightly higher than Thermomucor indicae-seudaticae N31 with 60.5 $\mathrm{U} / \mathrm{ml}$ [24] and Aspergillus flavo furcatis DPUA 1493 with 68.61 U/ml [25]; while it is lower than MCE activity detected in Termitomyces clypeatus with $333.33 \mathrm{U} / \mathrm{ml}$ [26].

The MCE from oyster (Pleurotus florida 14 MICC) mushroom formed a strong clot with forming quite whey after adding the enzymatic extract in skim milk solution (Figure 1). A similar result of clot formation was observed by Alecrim et al. (2014) [25] and Martim et al. (2017) [7], who detected MCE in Aspergillus flavo furcatis DPUA 1493 and Pleurotus albidus DPUA 1692, respectively.

Table 1. Extraction of MCE from oyster (Pleurotus florida) mushroom.

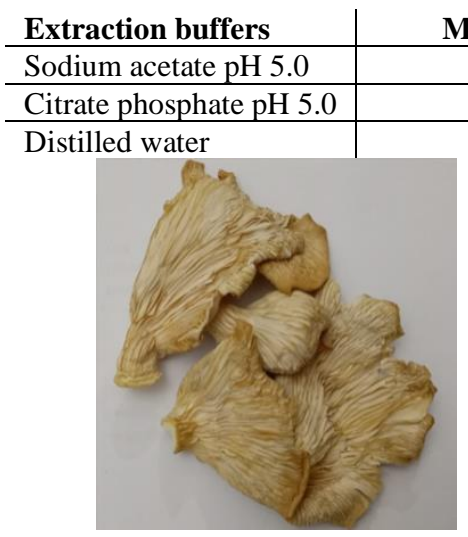

(a) MCE activity (SU/ml) MCE specific activity (SU/mg)

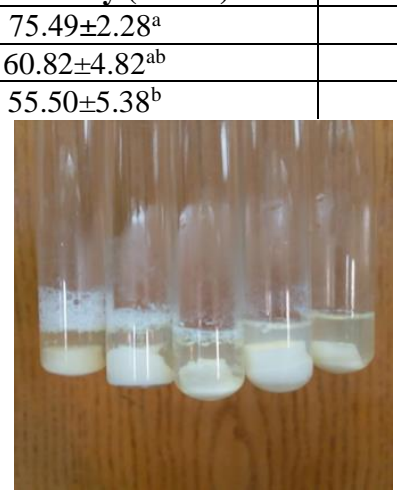

(b)

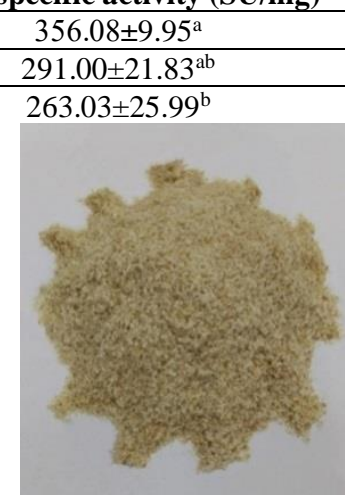

(c)

Figure 1. Oyster (Pleurotus florida $14 \mathrm{MICC}$ ) mushroom and their milk clotting activity.

(a) Dried fruiting bodies of mushrooms. (b) Dried mushroom powder. (c) Whey formed in the milk clotting test.

\subsection{Purification of MCE from oyster mushroom.}

MCE was partially purified from dried oyster mushroom (Pleurotus florida 14 MICC) using ASP procedure. Table 2 shows that the highest total MCE activity (367.85 SU) was 
recorded at $20 \%$ saturation of ammonium sulfate with specific MCE activity of $343.79 \mathrm{SU} \mathrm{mg}^{-}$ ${ }^{1}$ protein as well as the MCE was partially purified 1.01-fold from the crude extract of oyster mushroom with a yield of $24.36 \%$. Also, mushroom MCE activity gradually decreased with ammonium sulfate saturation increased, affecting the resulted yield and purification fold (data not shown). This result is in agreement with Nestor et al. (2012) [27], who reported that the highest MCA of Solanum elaeagnifolium seeds extract was recorded at $20 \%$ of ammonium sulfate, as well as $20-40 \%$ saturation of ammonium sulfate precipitated MCE from prepared seed cake of Moringa oleifera [28]. However, low saturation of ammonium sulfate is superior to high concentrations usually used to purify MCE from different plants [29, 30].

Mushroom MCE was further purified using size exclusion column chromatography on Sephadex G-100, as shown in Figure 2. It could be noted that MCE activity was observed in one peak among 40 collected fractions with maximal activity in fraction no. 18 (67.8 SU/ml). Also, the purification of MCE using Sephadex G-100 column recovered 17.96\% with 3.46 as a purification fold where the total MCE activity was $271.20 \mathrm{SU}$ with $1232.73 \mathrm{SU} / \mathrm{mg}$ protein as specific activity (Table 2). The final MCE recovery is similar to that obtained from previously described laboratory-scale procedures by Lebedeva and Proskuryakov (2009) [31], which purified MCE from oyster mushroom (Pleurotus ostreatus (Fr.) Kumm).

Table 2. Purification results of MCE from oyster (Pleurotus florida) mushroom.

\begin{tabular}{c|c|c|c|c|c|c|c}
$\begin{array}{c}\text { Purification } \\
\text { steps }\end{array}$ & $\begin{array}{c}\text { Total } \\
\text { Activity* } \\
\text { (SU) }\end{array}$ & $\begin{array}{c}\text { Total } \\
\text { protein* } \\
\text { (mg) }\end{array}$ & $\begin{array}{c}\text { Specific } \\
\text { activity } \\
\text { (unit/mg } \\
\text { protein) }\end{array}$ & $\begin{array}{c}\text { Proteolytic } \\
\text { activity } \\
\text { (PA) (U/ml) }\end{array}$ & $\begin{array}{c}\text { MCA/PA } \\
\text { ratio }\end{array}$ & $\begin{array}{c}\text { Yield } \\
(\%)\end{array}$ & $\begin{array}{c}\text { Purification } \\
\text { fold }\end{array}$ \\
\hline Crude enzyme & 1509.80 & 4.24 & 356.08 & 2.39 & 31.59 & 100 & 1.00 \\
\hline ASP (20\%) & 367.85 & 1.02 & 360.64 & 2.45 & 30.03 & 24.36 & 1.01 \\
\hline $\begin{array}{c}\text { SEC on Sephadex } \\
\text { G-100 }\end{array}$ & 271.20 & 0.22 & 1232.73 & 2.82 & 24.04 & 17.96 & 3.46
\end{tabular}

*Calculation based on $0.1 \mathrm{~g} / \mathrm{ml}$ of dried oyster mushroom in $0.1 \mathrm{M}$ sodium acetate buffer $\mathrm{pH}$ 5.0. Specific activity $=$ Enzyme activity/Protein content; Total activity= Enzyme activity X Fraction volume; Total protein= Protein content X Fraction volume; MCA, milk clotting enzyme activity (SU/ml); Yield= Total activity of purified enzyme/Total activity of crude enzyme X 100; Purification fold= Specific activity of purified enzyme/Specific activity of crude enzyme; ASP, Ammonium sulfate precipitation; SEC, Size exclusion column chromatography.

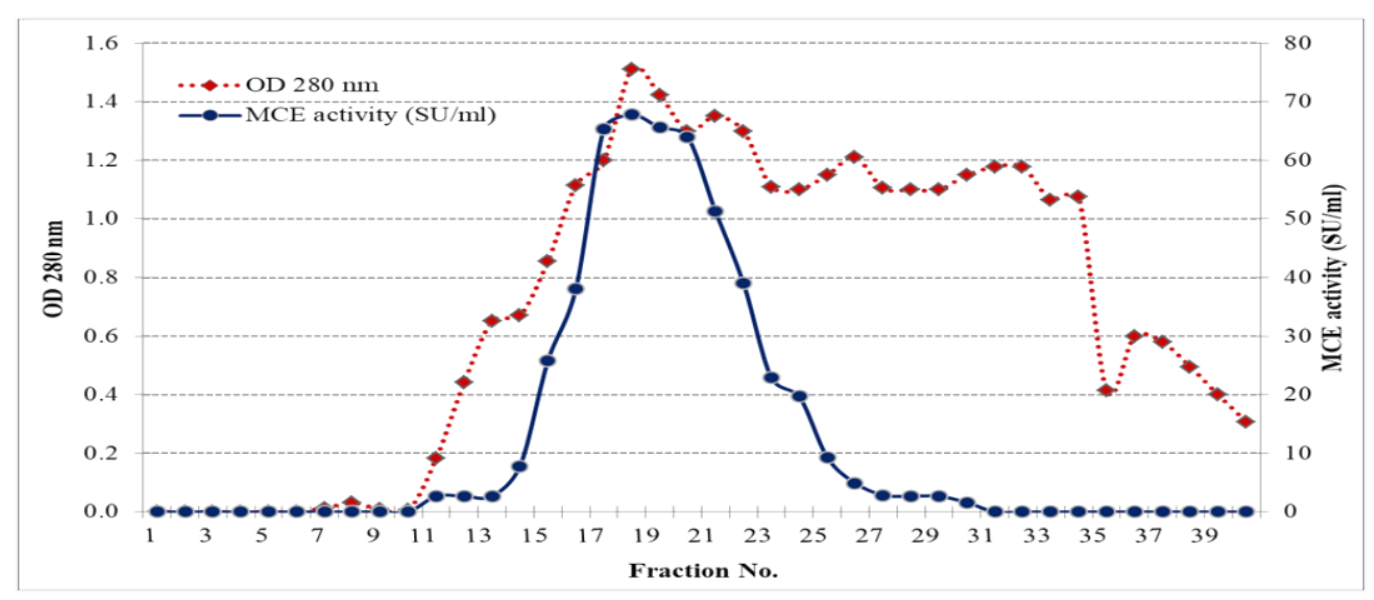

Figure 2. Size exclusion column chromatography of MCE from oyster mushroom on Sephadex G-100.

\subsection{Electrophoretic profile of mushroom MCE fractions.}

The electrophoretic profile of MCE fractions showed different bands in the crude fraction, which decreased in the partially purified fraction using ASP as presented in Figure 3; it could be due to the effect of the purification process. Moreover, SDS-PAGE of the purified 
MCE from oyster (Pleurotus florida 14 MICC) mushroom showed a single band with a molecular mass of about $45 \mathrm{kDa}$ (Figure 3). This finding is similar to MCE aspartic peptidase from basidiomycete Piptoporus soloniensis [32], basidiomycetous yeast Cryptococcus sp. S-2 [33], and Pleurotus ostreatus [34].

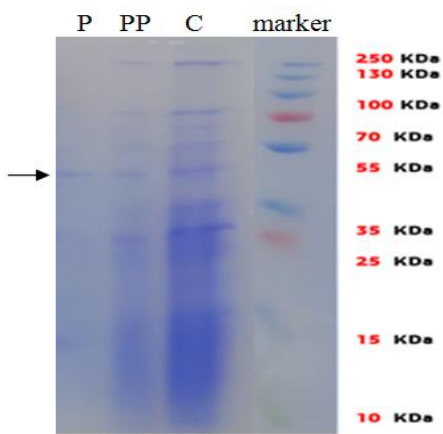

Figure 3. Electrophoretic profile of MCE factions from the oyster mushroom. (c) Crude extract. (PP) Partial purified MCE fraction. (P) Purified MCE fraction. The black arrow indicates the protein corresponding to purified MCE.

\subsection{Proteolytic activity of oyster mushrooms.}

The proteolytic activity (PA) of crude MCE extracted from oyster (Pleurotus florida 14 MICC) mushroom was $2.39 \mathrm{U} / \mathrm{ml}$ with a ratio of MCA/PA of 31.59 as shown in Table 2. Moreover, PA of partial purified MCE was $2.45 \mathrm{U} / \mathrm{ml}$, while the purified mushroom MCE recorded PA of $2.82 \mathrm{U} / \mathrm{ml}$ with a ratio of MCA/PA of 30.03 and 24.04, respectively. Hence, PA in the purified fractions was higher than a crude fraction; it could be due to the purification process since eliminating other components affects the overall PA of the resulting fractions (Figure 3). However, the relation of MCE activity and PA as a coagulation ratio is associated with the enzymatic specific in the clot formation, which influences the selection of MCE alternatives [25].

\subsection{Biochemical characterization of oyster mushroom MCE.}

Oyster (Pleurotus florida 14 MICC) mushroom MCE exhibited the optimal activity at $55{ }^{\circ} \mathrm{C}$ for the crude and partial purified extracts as shown in Figure 4, with a broad temperature range of $40-55{ }^{\circ} \mathrm{C}$ followed by gradually decreasing in their activity at 60 and $65{ }^{\circ} \mathrm{C}$, respectively. Moreover, the purified mushroom MCE recorded their maximal activity at $50{ }^{\circ} \mathrm{C}$. However, the optimum reaction temperature of mushroom MCE was similar to that found for MCE extracted from Pleurotus sajor-caju STCPI-27, and Pleurotus eryngii were $45{ }^{\circ} \mathrm{C}[13$, 35]; while it was quite lower than of MCE extracted from Pleurotus albidus [7], Rhizopus oryzae [36], Rhizopus microsporus var. rhizopodiformis [37] which observed at $60{ }^{\circ} \mathrm{C}$.

Figure 5 shows the optimal reaction $\mathrm{pH}$ for crude MCE of oyster mushroom was 5.0 while the purified and partial purified MCE was observed at $\mathrm{pH}$ 6.0. Also, neutral and alkaline $\mathrm{pH}$ reduces mushroom MCE for all resulted fractions. It could be due to the conformation changes in the protein structure caused by charge repulsion, where the distribution of charge in the protein surface and the conformations are modified, which affect the association between the MCE and milk protein as a substrate. Similar findings were reported by Sakovich et al. (2019) [34], who recorded that the highest MCE activity was shown at $\mathrm{pH}$ 5.0, meanwhile, Martim et al. (2017) [7] recorded the maximal activity of MCE from Pleurotus albidus at $\mathrm{pH}$ 6.0, and then the alkaline condition decreased its activity which only $19.37 \%$ was recorded at $\mathrm{pH}$ 10.0. Also, Pediococcus acidilactici SH exhibited high MCE activity at pH 6.0 [38], as well 
as Vishwanatha et al. (2010) [39] recorded high MCE activity at pH 6.3 from Aspergillus oryzae MTCC 5341 followed by the activity reduction of in higher $\mathrm{pH}$ values.

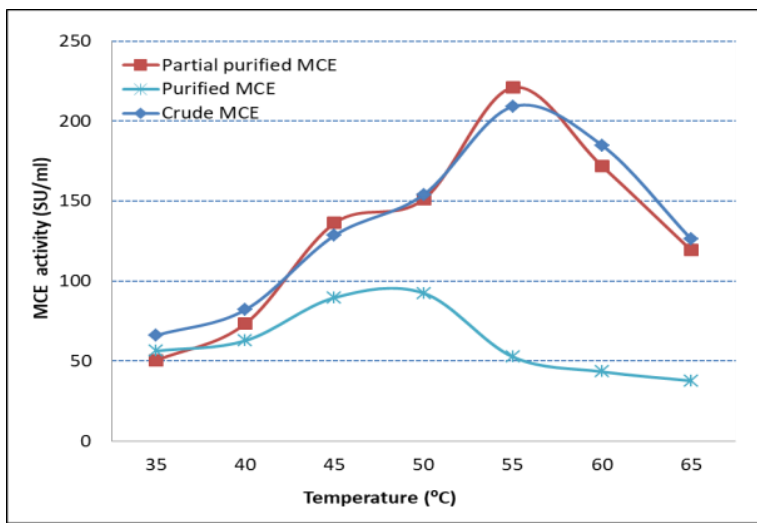

Figure 4. Temperature profile of MCE fractions from the oyster mushroom.

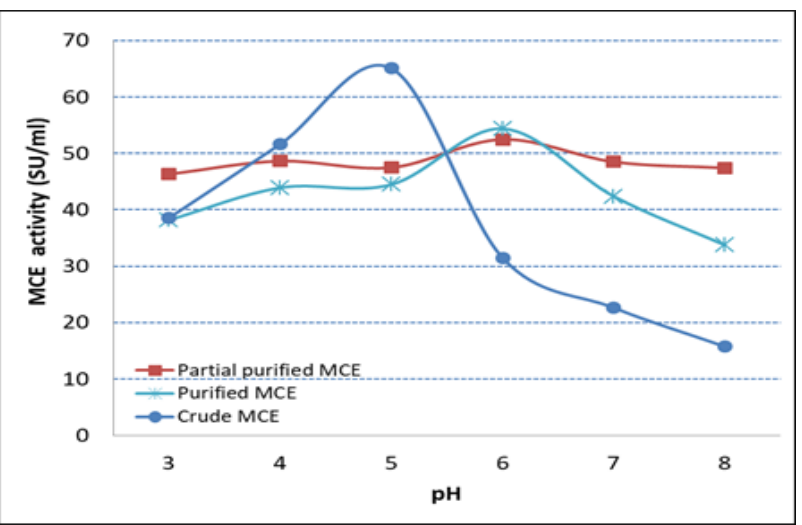

Figure 5. Optimal $\mathrm{pH}$ of MCE fractions from oyster mushroom.

The $\mathrm{CaCl}_{2}$ concentration $(0.01 \%)$ recorded the maximal MCE activity for crude MCE extracted from oyster mushrooms, followed by a gradual decrease in their activity, as shown in Figure 6. Moreover, purified and partially purified mushroom MCE activity increased until $0.02 \%$ and $0.04 \%$, respectively, after their activity decreased. However, it is well known that the non-enzymatic secondary phase, in which the aggregation of para-k-casein and other casein components occurs in association with $\mathrm{Ca}^{+2}$ ions and eventually results in the formation of a gel [40]. Also, Abd El-Salam et al. (2017) [41] reported that artichoke $\mathrm{MCE}$ required $\mathrm{Ca}^{+2}$ ions in the curd formation. Thus, clot formation is $\mathrm{Ca}^{+2}$ dependent [42]; it was confirmed with milk clotting enzyme extracted from mushroom, requiring suitable $\mathrm{CaCl}_{2}$ concentration for optimal activity.

Sodium chloride is widely used as a preservative and flavoring agent in food and dairy products $[43,44]$. Figure 7 shows that the mushroom MCE activity gradually decreased as the level of sodium chloride increased for all enzyme fractions. It could be due to inducing conformational changes in the enzyme molecule affected by a high sodium chloride level, which leads to a decrease in its MCE activity. Also, the addition of $\mathrm{NaCl}$ decreased the rate of MCE enzymatic reaction for coagulation [45]. These findings follow Ahmed et al. (2016) [46], who recorded the highest bacterial MCE activity extracted from Bacillus stearothermophilus at the lower level of $\mathrm{NaCl}$.

The thermal behavior of the enzyme is a useful property in the cheese-making process, as it can be quickly inactivated by moderate heating [47]. The thermal stability of all mushroom MCE fractions was shown in Figure 8. The results revealed that the residual MCE activity decreased as both temperature and pre-incubation time increased, which could be attributed to the conformational changes in the protein structure under high temperatures during the preincubation time. Also, the results indicated that the highest reduced activity of mushroom MCE after pre-incubation for $60 \mathrm{~min}$ at $40{ }^{\circ} \mathrm{C}$ is $\sim 12,28$, and $36 \%$ for crude, partially purified, and purified MCE fractions, respectively. Moreover, all mushroom MCE fractions activities were quickly diminished after incubation at 60-70 ${ }^{\circ} \mathrm{C}$. MCE from Termitomyces clypeatus MTCC 5091 was stable between 35 and $50{ }^{\circ} \mathrm{C}$ which retaining more than $80 \%$ of its activity, followed by a fast reduction of activity as the incubation temperature increased [26]. Also, Alecrim et al. (2014) [25] reported that MCE from Aspergillus flavo furcatis DPUA 1493 had thermal stability higher than $70 \%$ between 40 and $60{ }^{\circ} \mathrm{C}$, while in above temperature was decreased to $28 \%$. Thus, mushroom MCE exhibit higher thermal stability at $40{ }^{\circ} \mathrm{C}$ for all enzymatic 
fractions, while its stability at $50{ }^{\circ} \mathrm{C}$ is varied from $30 \mathrm{~min}$ for both crude and purified fractions. Hence, the thermal stability of mushroom MCE is similar to calf rennet since calf rennet reached its maximal activity at $45{ }^{\circ} \mathrm{C}$, followed by a sharp decline when the temperature exceeded $50{ }^{\circ} \mathrm{C}[48]$.

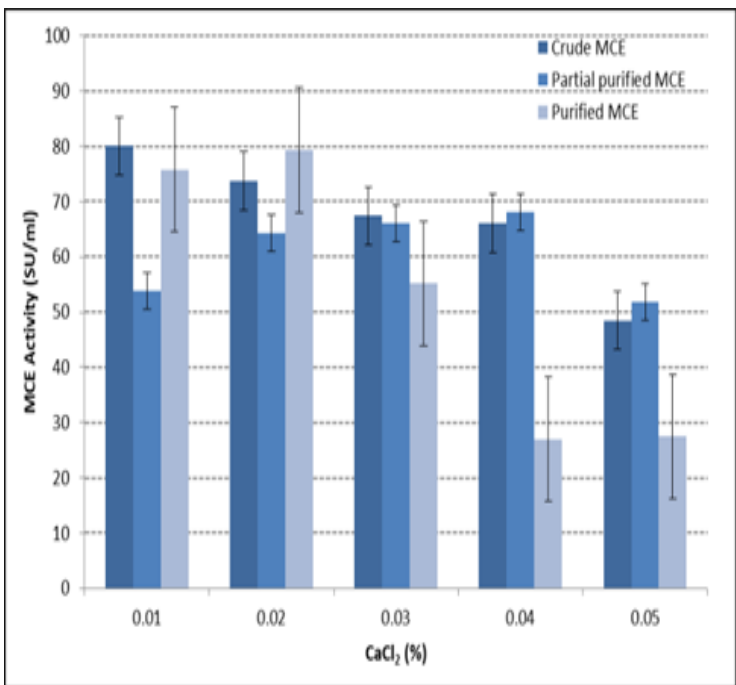

Figure 6. Effect of calcium chloride on MCE activity from oyster mushroom

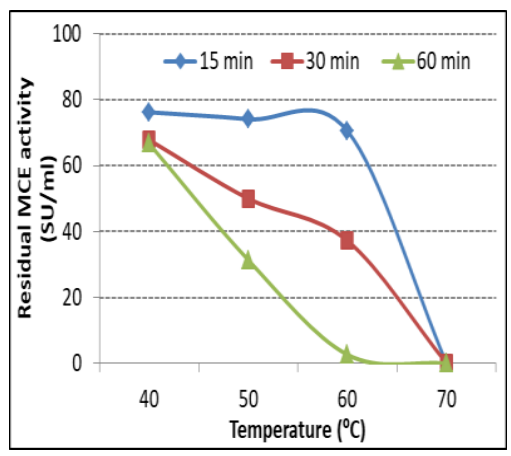

(a)

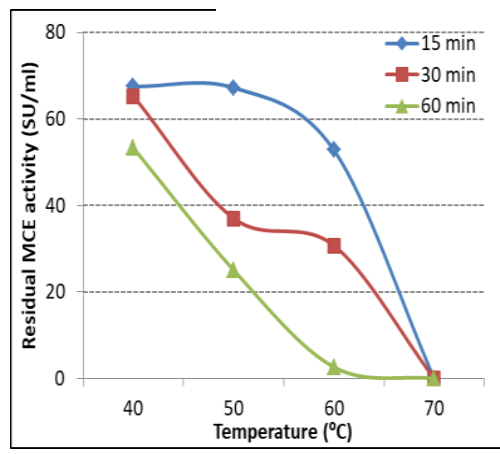

(b)

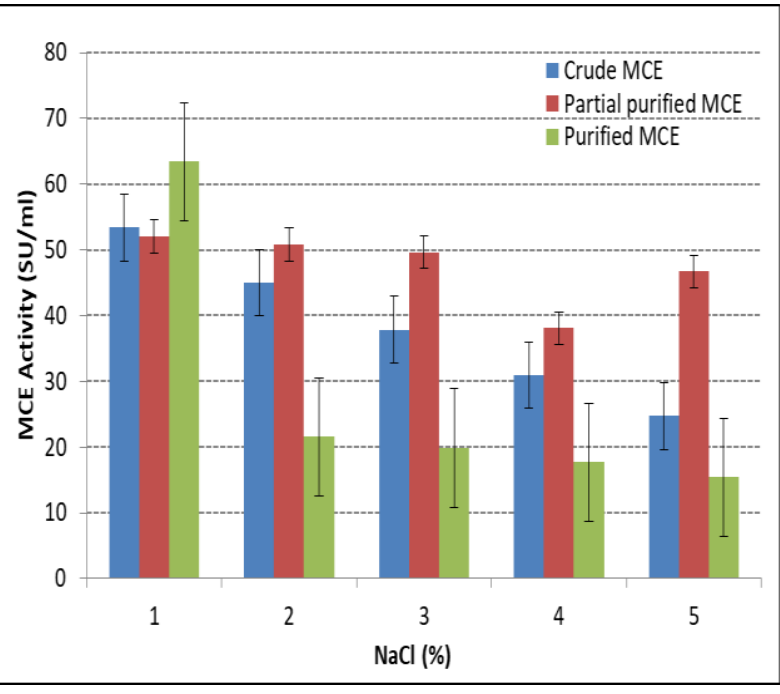

Figure 7. Effect of sodium chloride on MCE activity from oyster mushroom

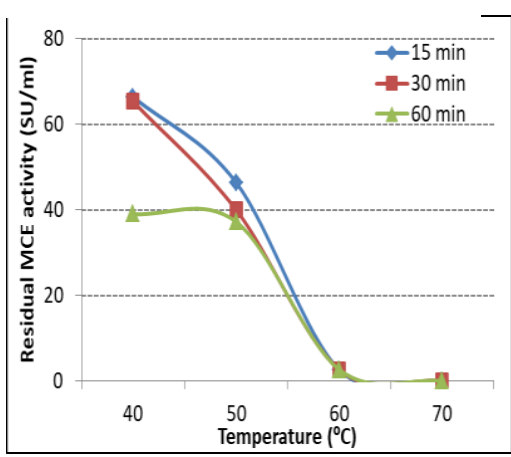

(c)

Figure 8. Thermal stability of MCE fractions from the oyster mushroom.

(a) Crude extract. (b) Partial purified MCE. (c) Purified MCE.

The suitability of mushroom MCE fractions towards different milk types, including cow, buffalo, goat, and sheep milk, was shown in Figure 9. Mushroom MCE could be capable of coagulating all examined milk types with various coagulation times started with cow milk followed by buffalo, sheep, and goat milk for both crude and partially purified MCE fractions, while the purified MCE recorded the shortest coagulation time for buffalo milk among other milk species followed by cow, sheep and goat milk. It could be due to the different compositional components of milk types, as well as the difference of casein fractions content among the examined milk species, which affects their coagulation time [49]. Park et al. (2007) [50] mentioned that the casein micelles diameter, hydration, and mineralization generally lead to shorter coagulating time, weaker gel consistency, and decreased yield of the cheese curd. Similar findings were reported by Barbagallo et al. (2007) [51] and Abdeen et al. (2021) [28], who observed the caprine, ovine and bovine milk coagulated with (Cynara cardunculus L.) flowers and Moringa oleifera of seed cake, respectively. Hence, the capability of oyster (Pleurotus florida 14 MICC) mushroom MCE for coagulation of various milk casein types supports their suitability to be used as a calf substitute in cheese making. 


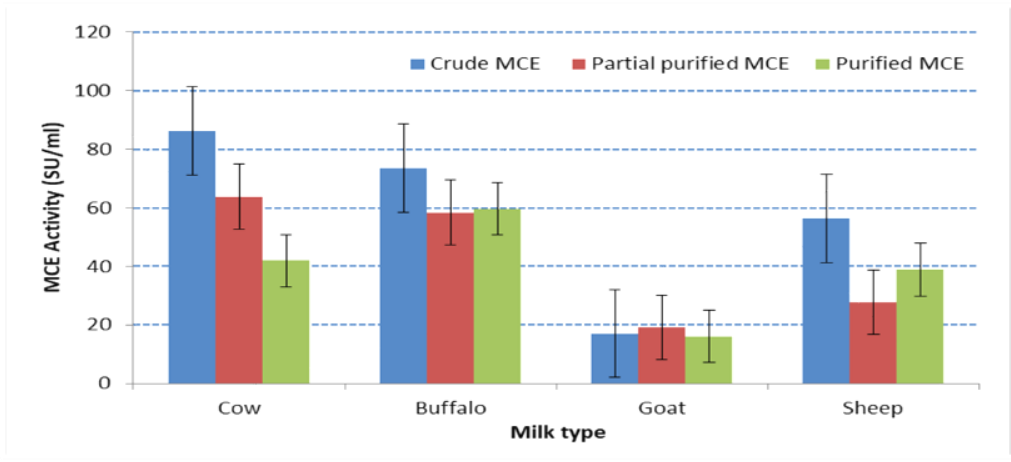

Figure 9. MCE activity on different milk species.

\section{Conclusions}

MCE isolated and purified from edible oyster (Pleurotus florida 14 MICC) mushroom fruit bodies showed thermal stability, as well as it could be capable of coagulating different milk species, including cow milk followed by buffalo, sheep, and goat milk. Mushroom MCE exhibited their optimal activity at $\mathrm{pH} 5.0$ for crude extract while at $\mathrm{pH} 6.0$ for other purified MCE fractions, at $55{ }^{\circ} \mathrm{C}$ for crude and partial purified MCE fractions while $50{ }^{\circ} \mathrm{C}$ for the purified MCE. Moreover, $\mathrm{CaCl}_{2}$ concentration $(0.01 \%)$ recorded the maximal activity for crude MCE while the purified and partially purified mushroom MCE activity increased to $0.02 \%$ and $0.04 \%$, respectively.

Thus, it could be concluded that MCE from Oyster (Pleurotus florida 14 MICC) mushroom be a good candidate as a calf rennet substitute in cheese production. Further studies will be examined its technological suitability for cheese production and its effect on the chemical, textural and sensory properties of the resulted cheese compared to commercial coagulants.

\section{Funding}

This research received no external funding.

\section{Acknowledgments}

This research has no acknowledgment.

\section{Conflicts of Interest}

The authors declare no conflict of interest.

\section{References}

1. Harboe, M.; Broe, M.L.; Qvist, K.B. The production, action and application of rennet and coagulants. In: Technology of cheese-making. $2^{\text {nd }}$ ed.; Law, B.A.; Tamime, A.Y. Eds.; Wiley-Blackwell, London, 2010; pp. 98-129.

2. Sousa, M.J.; Ardo Y.; McSweeney, P.L.H. Advances in the study of proteolysis during cheese ripening. Int. Dairy J. 2001, 11, 327-345, https://doi.org/10.1016/S0958-6946(01)00062-0.

3. Crabbe, M.J.C. Rennets: general and molecular aspects. In: Cheese: Chemistry, Physics and Microbiology. Fox, P.F.; McSweeney, P.L.H.; Cogan, T.M.; Guinee, T.P. Eds.; Elsevier, Amsterdam, 2004; pp. 19-46.

4. Agudelo, R.A.; Gauthier, S.F.; Pouliot, Y.; Marin, H.; Avoie, L.S. Kinetics of peptide fraction release during in vitro digestion of casein. J. Sci. Food Agric. 2004, 84, 325-333, https://doi.org/10.1002/jsfa.1662.

5. Roseiro, L.B.; Barbosa, M.; Ames, J.M.; Wilbey, R.A. Cheese-making with vegetable coagulants the use of Cynara L. for the production of ovine milk cheeses. Int. J. Dairy Technol. 2003, 56, 76-85, https://doi.org/10.1046/j.1471-0307.2003.00080.x. 
6. Cavalcanti, M.T.; Teixeira, M.F.; Lima Filho, J.L.; Porto, A.L. Partial purification of new milk-clotting enzyme produced by Nocardiopsis sp. Bioresource. Technol. 2004, 93, 29-35, https://doi.org/10.1016/j.biortech.2003.10.003.

7. Martim, S.R., Silva; de Souza, L.S.C.; do Carmo, L.B.; Alecrim, E.J.; de Vasconcellos, M.M.; Oliveira, I.M.de A; Teixeira, M.F.S. Pleurotus albidus: A new source of milk-clotting proteases. Afr. J. Microbiol. Res. 2017, 11, 660-667, https://doi.org/10.5897/AJMR2017.8520.

8. Yegin, S.; Fernandez-Lahore, M. A Thermolabile Aspartic Proteinase from Mucor mucedo DSM 809: Gene Identification, Cloning, and Functional Expression in Pichia pastoris. Mol. Biotechno. 2013, 54, 661-672, https://doi.org/10.1007/s12033-012-9608-6.

9. Jacob, M.; Jaros, D.; Rohm, H. Recent advances in milk clotting enzymes. Int. J. Dairy Technol. 2011, 64, 14-33, https://doi.org/10.1111/j.1471-0307.2010.00633.x.

10. Bensmail, S.; Boudjema, K.; Naimi-Fazouane, F. Production of extracellular rennin-like enzyme by a newly isolate Mucor circinelloides (von Tieghem) and its application in Camembert cheese making. J. Appl. Biotechnol. Rep. 2020, 7, 16-24, https://doi.org/10.30491/JABR.2020.105914.

11. Cirium, V.; Chinmayee Cheral, V.; Amsaraj, R.; Sridevi Annapurna, S. Production of highly active fungal milk-clotting enzyme by solid-state fermentation. Prep. Biochem. Biotechnol. 2019, 49, 858-867, https://doi.org/10.1080/10826068.2019.1630647.

12. Mamo, J.; Getachew, P.; Samuel Kuria, M.; Assefa, F. Application of Milk-Clotting Protease from Aspergillus oryzae DRDFS13 MN726447 and Bacillus subtilis SMDFS 2B MN715837 for Danbo Cheese Production. J. Food Quality 2020, 2020, 1-12, https://doi.org/10.1155/2020/8869010.

13. Moharib, S.A. Proteolytic activity of proteases produced from white rot fungus. Adv. Food Sci. 2007, 29, 611, https://api.semanticscholar.org/CorpusID:89359950.

14. Nakamura, k.; Kobayashi, N.; Tanimoto, M. Screening of Edible Mushrooms Producing Milk-clotting Enzyme. Nippon Shokuhin Kagaku Kogaku Kaishi 2014, 61, 444-44, https://doi.org/10.3136/nskkk.61.444.

15. Shamtsyan, M.; Dmitriyeva, T.; Kolesnikov, B.N.; Denisova, N. Novel milk-clotting enzyme produced by Coprinus lagopides basidial mushroom. Food Sci. Technol. 2014, 58, 343-347, https://doi.org/10.1016/j.lwt.2013.10.009.

16. Sato, K.; Goto, K.; Suzuki, A.; Miura, T.; Endo, M.; Nakamura, K.; Tanimoto, M. Characterization of a milkclotting enzyme from Hericium erinaceum and its proteolytic action on bovine caseins. Food Sci. Technol. Res. 2018, 24, 669-676, https://doi.org/10.11465/milk.65.161.

17. Colowick, S.P.; Kaplan, N. Methods in enzymology. Volume 1. Academic Press New York; 1955.

18. Laemmli, U.K. Cleavage of structural proteins during the assembly of the head of bacteriophage T4. Nature 1970, 227, 680-685, https://doi.org/10.1038/227680a0.

19. IDF. Bovine rennets. Determination of total milk-clotting activity. IDF standard, Volume 157, Brussels, Belgium; 1992.

20. Chopra, A.K.; Mathur, D.K. Factors affecting protease production by Bacillus stearothermophilus RM-67. J. Food Prot. 1983, 46, 1020-1025, https://doi.org/10.4315/0362-028X-46.12.1020.

21. Bradford, M.M. A rapid and sensitivity method for the quantitation of microgram quantities of protein utilizing the principle of protein-dye binding. Anal. Biochem. 1976, 72, 248-354, https://doi.org/10.1006/abio.1976.9999.

22. SAS Institute Inc. SAS User's Guide statistics Ver. 8, SAS Inst. Cary, NC, USA; 1999.

23. Téllez-Téllez, M.; Diaz-Godinez, G. Omic tools to study enzymes production from fungi in the Pleurotus genus. BioResourses 2019, 14, 2420-2457, https://doi.org/10.15376/biores.14.1.2420-2457.

24. Silva, B.L.; Geraldes, F.M.; Murari, C.S; Gomes, E.; Da-Silva, R. Production and Characterization of a milkclotting protease produced in submerged fermentation by the thermophilic fungus Thermomисо indicaeseudaticae N31. Appl. Biochem. Biotechnol. 2014, 172, 1999-2011, https://doi.org/10.1007/s12010-0130655-7.

25. Alecrim, M.M.; Palheta, R.A.; Teixeira, M.F.S.; Oliveir, M.A. Milk-clotting enzymes produced by Aspergillus flavo furcatis strains on Amazonic fruit waste. Int. J. Food Sci. Technol. 2014, 50, 151-157, https://doi.org/10.1111/ijfs.12677.

26. Majumder, R.; Banik, S.P.; Khowala, S. Purification and characterization of $\kappa$-casein specific milk-clotting metalloprotease from Termitomyces clypeatus MTCC 5091. Food Chem. 2015, 173, 441-448, https://doi.org/10.1016/j.foodchem.2014.10.027.

27. Nestor, G.; Rubí, C.D.; Hector, J. Exploring the milk-clotting properties of a plant coagulant from the berries of S. elaeagnifolium var. Cavanilles. J. Food Sci. 2012, 77, 89-94, https://doi.org/10.1111/j.17503841.2011.02468.x.

28. Abdeen, E.S.M.M.; Ibrahim, O.A.; Kholif, A.M.M. Utility of Moringa oleifera waste as a coagulant in goat soft cheese production. Heliyon 2021, 7, https://doi.org/10.1016/j.heliyon.2021.e07536.

29. Mohamed Ahmed, I.A.; Morishima, I.; Babiker, E.E.; Mori, N. Characterization of partially purified milkclotting enzyme from Solanum dubium Fresen seeds. Food Chem. 2009, 116, 395-400, https://doi.org/10.1016/j.foodchem.2008.11.072. 
30. Pontual, E.V.; Carvalho, B.E.; Bezerra, R.S.; Coelho, L.C.; Napoleão, T.H.; Paiva, P.M. Caseinolytic and milk clotting activities from Moringa oleifera flowers. Food Chem. 2012, 135, 1848-1854, https://doi.org/10.1016/j.foodchem.2012.06.087.

31. Lebedeva, G.V.; Proskuryakov, M.T. Purification and characterization of milk-clotting enzymes from oyster mushroom (Pleurotus ostreatus (Fr.) Kumm). Appl. Biochem. Microbiol. 2009, 45, https://doi.org/10.1134/S0003683809060088.

32. El-Baky, H.A.; Linke, D.; Nimtz, M.; Berger, R.G. PsoP1, a milk-clotting aspartic peptidase from the Basidiomycete Fungus Piptoporus soloniensis. J. Agri. Food Chem. 2011, 59, 10311-10316, https://doi.org/10.1021/jf2021495.

33. Rao, S.; Mizutani, O.; Hirano, T.; Masaki, K.; Iefuji, H. Purification and characterization of a novel aspartic protease from basidiomycetous yeast Cryptococcus sp. S-2. J. Biosci. Bioeng. 2011, 112, 441-446, https://doi.org/10.1016/j.jbiosc.2011.07.013.

34. Sakovich, V.V.; Stohnii, Y.M.; Zhernosekov, D.D.; Rebriev, A.V.; Korolova, D.S.; Marunych, R.Y.; Chernyshenko, V.O. Metalloprotease from the cultural liquid of Pleurotus ostreatus. Biotechnol. Acta 2019, 12, 35-45, https://doi.org/10.15407/biotech12.06.035.

35. Hu, Q.X.; Zhang, G.Q.; Zhang, R.Y.; Hu, D.D.; Wang, H.X.; Ng, T.B. A novel aspartic protease with HIV1 reverse transcriptase inhibitory activity from fresh fruiting bodies of the wild mushroom Xylaria hypoxylon. J. Biomed. Biotechnol. 2012, 2012, 33-36, https://doi.org/10.1155/2012/728975

36. Kumar, S.; Sharma, N.S.; Saharan, M.R.; Singh, R. Extracellular acid protease from Rhizopus oryzae: purification and characterization. Process. Biochem. 2005, 40, 1701-1705, http://doi.org/10.1016/j.procbio.2004.06.047.

37. Sun, Q.; Wang, X.P.; Yan, Q.J.; Chen, W.; Jiang, Z.Q. Purification and characterization of a chymosin from Rhizopusmicrosporus var. rhizopodiformis. Appl. Biochem. Biotechnol. 2014, 174, 174-185, http://doi.org/10.1007/s12010-014-1044-6.

38. Imdakim, M.; Hassan, Z.; Mohamed, M.; Brahim, M.; Muhialdin, B. Milk clotting and proteolytic activity of enzyme preparation from Pediococcus acidilactici SH for dairy products. Afri. J. Biotechnol. 2015, 14, 133142, http://doi.org/10.5897/AJB2014.13974.

39. Vishwanatha, K.S.; Appu Rao A.G.; Singh, S.A. Production and characterization of a milk-clotting enzyme from Aspergillus oryzae MTCC 5341. Appl. Microbiol. Biotechnol. 2010, 85, 1849-1859, http://doi.org/10.1007/s00253-009-2197-z .

40. Esteves, C.; Lucey, J.; Pires, E. Mathematical modelling of the formation of rennet-induced gels by plant coagulants and chymosin. J. Dairy Res. 2001, 68, 499-510, http://doi.org/10.1017/S0022029901005027.

41. Abd El-Salam, B.A.; Ibrahim, O.A.; El-Sayed, H.A. Purification and characterization of milk clotting enzyme from artichoke (Cynara cardunculus L.) flowers as coagulant on white soft cheese. Int. J. Dairy Sci. 2017, 12, 254-265, http://doi.org/10.3923/ijds.2017.254.265.

42. Sidrach, L.; Garcia-Canovas, F.; Tudela, J.; Rodriguez-Lopez, J. Purification of cynarases from artichoke (Cynara scolymus): Enzymatic properties of cynarase A. Phytochemist. 2005, 66, 41-49, http://doi.org/10.1016/j.phytochem.2004.10.005.

43. Walstra, P.; Geurts, T.J.; Noomen, A.; Jellema, A.; Van Boekel, M.A. Principles of milk properties and processes. Dairy Technology $2^{\text {nd }}$ ed. New York. Marcel Dekker. 1999.

44. Guinee, Tim; Fox, P.F. Salt in Cheese: Physical, Chemical and Biological Aspects. Cheese: Chemistry, Physics and Microbiology 2004, 1, 207-259, http://doi.org/10.1016/S1874-558X(04)80069-1.

45. Zoon, P.; Van Vliet T.; Walstra, P. Rheological properties of rennet-induced skim milk gels. 4. The effect of $\mathrm{pH}$ and $\mathrm{NaCl}$. Neth. Milk Dairy J. 1989, 43, 17-34.

46. Ahmed, S.; Wehaidy, H.; Ibrahim, O.; Hassan, S.; El-Hofi, M. Novel milk-clotting enzyme from Bacillus stearothermophilus as a coagulant in UF-white soft cheese. Biocatal. Agric. Biotechnol. 2016, 7, 241-249, https://doi.org/10.1016/j.bcab.2016.06.011.

47. Llorente, B.E.; Brulti, C.B.; Natalucci, C.L.; Caffini, N.O. Partial Characterization of a Milk Clotting Proteinase isolated from Artichoke (Cynara scolymus L., Asteraceae). Acta Farm Bonaerense. 1997, 16, 3742.

48. Shehata, A.E.; Fayet, E.A.; Ismail, A.A.; Salem, M.M. Production and characterization of bacterial coagulants as calf rennet replace for Egyptian cheese making. E.J.F.S. 1996, 24, 417-449.

49. Medhammar, E.; Wijesinha-Bettoni, R.; Stadlmayr, B.; Nilsson, E.; Charrondiere, U.R.; Burlingame, B. Composition of milk from minor dairy animals and buffalo breeds: a biodiversity perspective. J. Sci. Food Agric. 2012, 92, 445-74, https://doi.org/10.1002/jsfa.4690.

50. Park, Y.; Juárez, M.; Ramos, M.; Haenlein, G.F.W. Physico-chemical characteristics of goat and sheep milk. Small Ruminant Res. 2007, 68, 88-113, https://doi.org/10.1016/j.smallrumres.2006.09.013.

51. Barbagallo, R.N.; Chisari, M.; Spagna, G.; Ierna, A.; Patanè, A.; Occhipinti, A.; Mauromicale, G. casinolytic activity expression in flowers of Cynara cardunculus. Acta Hortic. 2007, 730, 195-199, https://doi.org/10.17660/ActaHortic.2007.730.24. 